\title{
ECOLOGICAL MEASURES IN THE LAND CONSOLIDATION PLANNING OF THE VILLAGE OF KOCURANY
}

\author{
ANDREA DIVIAKOVÁ ${ }^{1}$, DUŠAN KOČICKÝ ${ }^{2}$, ELIŠKA BELAŇOVÁ ${ }^{1}$ \\ ${ }^{1}$ UNESCO-Chair on Sustainable Development and Ecological Awareness, Faculty of Ecology and Environmental Sci- \\ ences, Technical University in Zvolen, T. G. Masaryka 24, 96053 Zvolen, Slovak Republic; e-mail: andreadiviakova@ \\ gmail.com, belanova@tuzvo.sk \\ ${ }^{2}$ Esprit, s.r.o., Pletiarska 1, 96900 Banská Štiavnica, Slovak Republic; e-mail: kocicky@esprit-bs.sk
}

\begin{abstract}
Diviaková A., Kočický D., Belaňová E.: Ecological measures in the land consolidation planning of the village of Kocurany. Ekológia (Bratislava), Vol. 38, No. 1, p. 69-86, 2019.

This paper deals with the application of ecological proposals within the land consolidation project process in Slovakia. Ecological proposals form part of the Local Territorial System of the Ecological Stability project, which is a compulsory material for developing land consolidation projects. The Local Territorial System of Ecological Stability for the cadastral unit of Kocurany village was worked out in 2013. Within the area, 31 localities were selected for the implementation of ecological proposals with a total area of 154.34 ha, namely 3 biocorridors, 2 biocentres, 9 interacting elements, 8 ecostabilising elements and 9 localities with the need of anti-erosion soil cultivation, or delimitation to permanent grasslands. The main task was to analyse the rate of acceptance of the proposed measures. It was found that only 20 localities with a total area of 119.37 ha were accepted into the land consolidation project. In order to improve all the landscape functions, the integration of quality ecological proposals from the Territorial System of Ecological Stability into the land consolidation projects is necessary.
\end{abstract}

Key words: Territorial System of Ecological Stability, land consolidation, ecological proposals, local level.

\section{Introduction}

Land consolidation (LC) in the Slovak Republic and in most European Union countries constitutes an activity whose objective is to aid purposeful and rational organisation of the agricultural landscape. Additionally, it helps in the protection and development of this landscape. In different countries and regions, the aims and methods of LC are influenced by specific conditions, their historical and current political and social development, their natural conditions, as well as the official (information) price of agricultural land (Eichenauer, Joeris, 1994; Bonfanti et al., 1997; Borec, 2000; Crecente et al., 2002; Sklenička, 2002; Gorton, White, 2003; Muchová et al., 2018).

The current state of LC planning in Slovakia is especially affected by specific historical developments within the former Czechoslovakia. After the year 1948, LC was dealt with on 
the basis of regulations, so-called economic and technical modifications in Czechoslovakia. Their meaning was subordinated to the economic aims, agricultural industrialisation and political demands of that period. The regulations principally involved the formation of large blocks of land. The prior ownership of this land was not considered, and a sensitive approach to the landscape was often absent. The agricultural landscape was transformed considerably, especially in intensively cultivated agricultural areas (Kaulich, 2012). The Slovak landscape underwent a big reorganisation. Areas that were originally divided into severalhectare fields, were transformed into large, several hundred hectare blocks of arable land by the process of collectivisation in the 1950s. During this process, the 'dividing' elements were removed from the landscape. These elements included important biotic elements such as vegetation of balks, hedges, ecotones and verges alongside roads. After their removal, a considerable decrease in biodiversity and overall ecological stability occurred across large areas of the landscape. The changes in the spatial landscape organisation were also felt in the form of an increase in some negative processes on arable land - especially soil erosion. The overall reaction of the landscape to agricultural activities is different on big blocks and on small blocks of land. Moreover, large areas of agricultural land are usually owned by several landholders (fragmentation of landholding). This does not allow an independent use of land parcels by individual landholders. Access from public or local roads is not ensured to every parcel. Several land parcels are of unsuitable shape and have a small surface area. The land parcels are often co-owned by several landholders. For these reasons, they are left for rent to a common user. Bigger fragmentation of landholding and related limitations on use lead to farming on larger blocks of agricultural land. Due to these factors, the landscape becomes more homogeneous, and therefore, less stable and less ecologically valuable.

However, if the landholders own land parcels, whose surface area and shape enable their individual use or rental, the agricultural landscape is divided into a lot of smaller blocks of arable land. The land parcels create a varied landscape mosaic. They are separated by balks, hedges, ecotones and verges, which fulfil many important ecological and environmental functions (Urban et al., 2013).

Such linear elements are important landscape elements affecting biodiversity. They allow different kinds of plants and animals to move among fragmented biotopes (Forman, Baudry, 1984; Opdam et al., 1995; Bennet, 1999). Motion of different kinds of plants and animals down the corridors has been demonstrated by many authors (e.g., Mann, Plummer, 1995; Rosenberg et al., 1997; Roy, Blois, 2008). They are considered to be sustainable landscape elements and they should have their own administrative management (Baudry et al., 2000).

The current organisation of landholding by LC enables the execution of property rights and users' relations to the land parcels in Slovakia. The variety within the landscape is thus increased and its ecostabilising, retentive, anti-erosional and biotic functions and other biodiversity supporting functions are improved and 'greening of the landscape' is performed. From this viewpoint, the Territorial System of Ecological Stability (TSES) is an important tool in the process of LC in Slovakia (Law No. 330/1991 Coll.). The concept of the TSES in Slovakia is fully convergent with other laws, which have been created and applied to landscapes internationally (e.g., Buček, Lacina, 1979; Buček et al., 1986; Löw et al., 1988; Míchal et al., 1991; Míchal, 1992; Buček, Lacina, 1993; Forman, Godron, 1993; Smith, Helmund, 1993; 
Bastian, Schreiber, 1994; Jedicke, 1994; Naveh, Lieberman, 1994; Lammers, Zadelhoff, 1996; Bani et al., 2002; Izakovičová, Swiader, 2017 ).

The TSES represents an ecological network that contains spatially related, ecologically stable segments of the landscape. These elements are functionally distributed on the basis of their functional and spatial criteria. Methodologies of this specialisation are known all over the world (Cook, van Lier, 1994; Brandt, 1995; Jongman, 1995; Sepp, Kaasik, 2002; Jongman et al., 2004; Wrbka et al., 2005; Fabos, 2005; Jongman, 2008). It is a modern concept for the protection of nature and biodiversity, based on the principles of protection of conditions and forms of biota, that is, geobiodiversity protection (Miklós et al., 2011). The TSES consists of biocentres (ensuring a food chain, conditions for reproduction, recreation and shelter), biocorridors and interacting elements (allowing migration and exchange of genetic information, as well as interactions of different ecosystems of different stability). It is processed at three hierarchical levels: local, regional and national. A local level of the TSES (LTSES) is important for the land consolidation.

Several authors deal with the importance of a LTSES in LC, and with the principles of creation of LTSES projects for the needs of LC, for example, Dumbrovský, Kolárová, 1995; Izakovičová et al., 2000; Zelinka, 2001; Ružičková, 2006; Muchová et al., 2013; Kocián, 2013; Belaňová, Diviaková, 2015; Doubrava, Martének, 2015; Julény et al., 2017. The areas of the Natura 2000 network of protected European sites are fully or partially considered in relation to the land consolidation (Hootsmans, Kampf, 2004; Ružičková, 2006).

A guidance framework for the creation and implementation of LTSES projects inland consolidation includes a methodological manual for land consolidation planning, issued by the Ministry of Agriculture and Rural Development of the Slovak Republic (2004) and the Methodological Standards for Designing Land Consolidations (Muchová et al., 2009).

The project of land consolidation is worked out within the LC district in the following steps: introductory materials, proposal of new arrangement of land parcels, implementation of the project. The proposal of the LTSES and ecostabilising measures is a part of the proposal of the General Principles of Functional Organisation of the Territory (GPFOT). These proposals are worked out during the preparation of introductory materials of the land consolidation project.

This paper deals with the protection and development of the agricultural landscape in the LC project district of the village of Kocurany. It focuses on the proposal of structure of the LTSES and anti-erosion measures, and subsequently, it monitors the integration of ecological measures into the proposal of GPFOT.

\section{Material and methods}

The area under discussion belongs to the district of the LC project of the village of Kocurany (latitude of $48^{\circ} 46^{\prime} 17^{\prime \prime} \mathrm{N}$; longitude of $\left.18^{\circ} 32^{\prime} 35^{\prime \prime} \mathrm{E}\right)$. It is situated in the north-western part of the Slovak Republic, in the region of Prievidza (Fig. 1). The total area of the land parcels in the area is 332.48 ha. Geological conditions are determined by the area's position in a border part of the Hornonitrianska kotlina basin of characteristic tectonic composition. The basin is filled with neogene and paleogene sediments. There are Mesozoic and Crystalinicum rocks of Malá Magura in their bedrock. Cambisols predominate among the soil types, and adjacent to the watercourses, there are fluvisols and fragmental rendzinas. According to the phytogeographical structure (Miklós, Hrnčiarová, 2002), the area belongs to the beech zone, Crystalline-Mesozoic area and to the region of the Hornonitrianska kotlina basin. The following 
units of potential natural vegetation were identified (Michalko et al., 1986): bottomland forests, lowland forests, oak and hornbeam Carpathian forests, oak and silverweed forests, oak and European turkey oak forests. The area is an open agricultural landscape. Permanent grasslands, forest vegetation and arable land are dominant. Formations of non-forest woody vegetation are the important elements of the landscape structure. In the area under discussion, there are the following types of biotopes (Ružičková et al., 1996): oak and hornbeam Carpathian forests (Carici pilosae-Carpinenion betuli), submontane alder bottomland forests (Stellario-Alnetum glutinosae), blackthorn scrubs (Ligustro-Prunetum), shrub covers of mesophilic forest covers, lowland and submontane oatgrass meadows (Arrhenatherion), poor submontane and montane meadows (Polygalo-Cynosurenion), reed communities of still water and marsh and submontane stream. Two watercourses flow through the territory: Trebianka and Jeleškový streams. The territory is drained by the river Nitra.

The agricultural production is realized through the Kolesi cooperative. The forests are managed by Forest and Land Association Kocurany. The following stress factors have been identified in the territory: large-scale arable land, Route III. classes, horse-breeding grounds, line equipment of technical infrastructure (telecommunication lines, water mains, gas pipelines and electric conduits), deforestation, air pollution, soil contamination, surface water pollution and soil damage by water erosion. The coefficient of ecological stability in the area is 2.79 (average ecological stability).

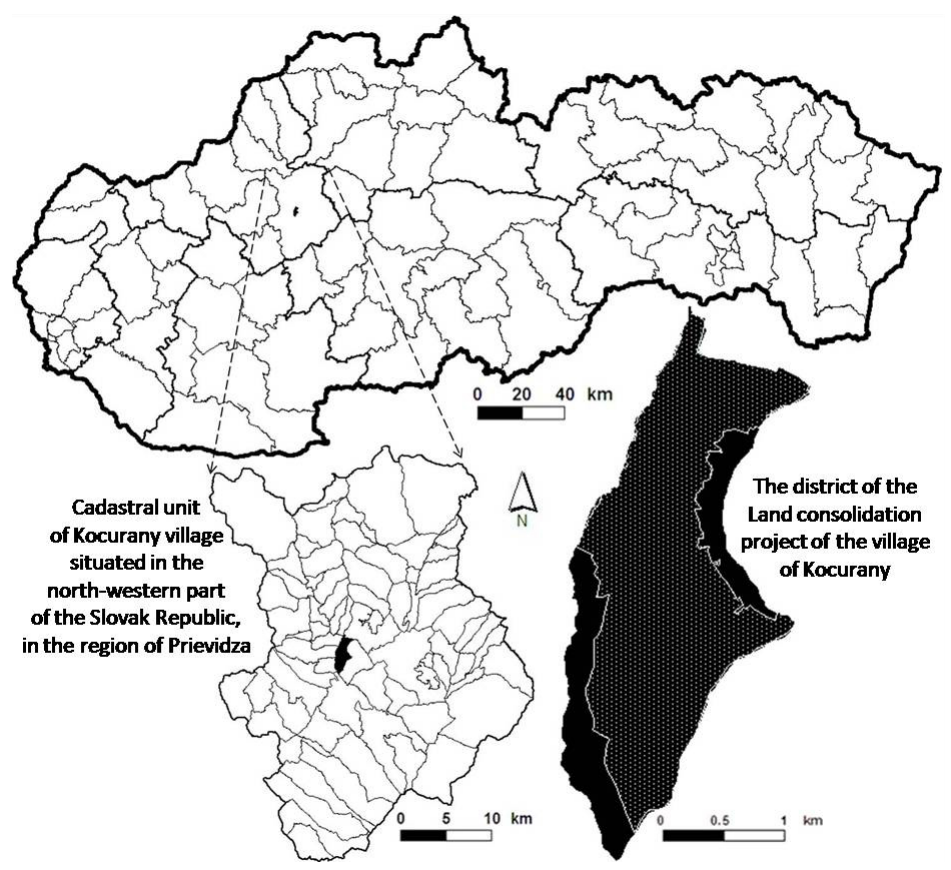

Fig. 1. The location of the area under discussion within the administrative organisation of the Slovak Republic.

The project of LTSES Kocurany for the purposes of LC (Diviaková et al., 2013) was worked out in accordance with the Methodological Standards for Designing Land Consolidations (Ministry of Agriculture and Rural Development of the Slovak Republic, 2004). The working procedure consisted of 3 basic parts:

- analysis of accessible materials, natural conditions and the current landscape structure, 
- $\quad$ syntheses and evaluations focused on areal and spatial organisation of positive and negative elements and phenomena, and on the assessment of ecological stability and landscape structure,

- $\quad$ proposal of the TSES structure and anti-erosion measures.

The proposal of General Principles of Functional Organisation of the Territory was worked out by the project architects of LC within the Kocurany LC project (Krchňavá et al., 2013) on the basis of the proposal of the TSES structure and anti-erosion measures, with the specification based on more detailed knowledge and proposals, as well as comments and requirements of the participants of the LC.

From the introductory materials of the LC project, the elements of the structure were analysed in the first part (biocenters, bioccoridors and interacting elements), along with the proposal for anti-erosion measures in the LTSES project. Subsequently, the proposal for GPFOT was analysed. In the last step, the rate of integration of ecological measures from the LTSES to GPFOT was assessed.

\section{Results}

Analysis of the proposed structure of the Local Territorial System of Ecological Stability and anti-erosion measures

In the district of the Kocurany land consolidation project, one biocorridor of regional importance $(\mathrm{RBCl})$ was reflected in the proposed structure of the LTSES from the project of Regional Territorial System of Ecological Stability Prievidza (Múdry et al., 1994). RBc1 Š́tovský stream and its environs, ecotones Háje, represent a regional hydric and terestric biocorridor (only a part of the biocorridor is involved in the district of the LC project). The biocorridor is created by submontane watercourse and its bank cover. In the northern part, it borders the western frontier of the discussed area, and in this part, the watercourse is not regulated. It is created by natural bank cover (Alnus glutinosa, Salix sp., and Corylus avellana in some parts of the undergrowth). Bank cover on the right side changes continuously into forest cover. Cover of submontane firs, undermined by water, is a part of the northern part of the biocorridor. In the southern part of the area, the biocorridor goes through ecotone communities of the forest cover.

13 existing elements of local importance were set aside: 2 local biocentres (LBcr2 Nádavky, LBcr3 Háje), 2 local biocorridors (LBc4 Homôlky, LBc5), 9 interacting elements (IE6 Slivčina, IE7 Slivčina, IE8 Zadné diely, IE9 Zadné diely, IE10 Zadné diely, IE11 Lány, IE12 Zadné diely, IE13 Krížne cesty, IE14 Zadné diely). LBcr2 Nádavky represents a terrestrial local biocentre, created by the formations of non-forest woody vegetation, forest cover and partially grass and herbaceous covers with woody plant succession. In the formations of non-forest woody vegetation, Scots pine (Pinus sylvetris) and European hornbeam (Carpinus betulus) are dominant; the ecotone is created by blackthorn (Prunus spinosa). There are also other species, for example, field maple (Acer campestre), common oak (Quercus robur), old man's beard (Clematis vitalba), wild privet (Ligustrum vulgare), common hazel (Corylus avellana), rubus (Rubus sp.), common hawthorn (Crataegus monogyna), rowan (Sorbus aucuparia), wild service tree (S. torminalis), whitebeam (S. aria), common dogwood (Swida sanquinea), European beech (Fagus sylvatica), silver birch (Betula pendula), common juniper (Juniperus communis), dog rose (Rosa canina), aspen (Populus tremula), European wild pear (Pyrus pyraster) and so on. Due to the variety of communities, the local biocentre is an important biotope in the discussed area, which provides permanent conditions for the 
existence of biota of the area. It is also an important ecostabilising element. LBcr3 Háje is a local biocentre comprising forest, partially grass and herbaceous covers, with the occurrence of formations of non-forest woody vegetation. The forests contain predominantly pine and oak covers. The main woody plants are: sessile oak (Quercus petraea), common oak ( $Q$. robur), Scots pine (Pinus sylvestris) and European hornbeam (Carpinus betulus). The ecotone of these communities consists mainly of blackthorn (Prunus spinosa). The local biocentre in the discussed area is an important biotope, providing permanent conditions for the reproduction, shelter and nutrition of living organisms and for the conservation and natural development of their communities. LBc4 Homôlky is a local terestric biocorridor. It is a large multi-level formation of non-forest woody vegetation of linear shape, stretching into the upper part of the discussed area along its western border. Species composition of the woody plants and shrubs is varied, including taxa from the surrounding forest covers, as well as attractive species from the point of view of fruit production serving as a source of food for animals (Prunus spinosa, Pyrus pyraster etc.). The element gives ideal conditions for the migration of different fauna. During the field research, several species of birds were registered and migrations of animals including wild boar (Sus scrofa), fallow deer (Dama dama), European roe deer (Capreolus capreolus) were observed. With respect to wider relations, the local biocorridor forms a large part of the immediate regional biocorridor $\mathrm{RBcl}$. Together, they form one of the most important ecological and stabilising segments of the discussed area. The described formation of non-forest woody vegetation also fulfils a significant anti-erosion function. LBc5 Jeleškový potok stream forms a local hydric and terestric biocorridor (only a part of the biocorridor reaches the district of the LC project). It is a submontane watercourse with a gentle slope, which forms part of the north-eastern border of the discussed area. The watercourse is not regulated. In its immediate surroundings, there are narrow lines of bank covers, which contain common alder (Alnus glutinosa) and shrubs (Rosa sp.) scattered in the undergrowth. Near the watercourse, the soil is undermined by water in some places, with the presence of rushes (Juncus sp.). Interacting elements (IE6, IE7, IE8, IE9, IE10, IE11, IE12, IE13, IE14) predominantly represent formations of non-forest woody plant vegetation, forest covers, or meadows with a certain proportion of non-forest woody plant vegetation. They are connected with biocentres and biocorridors and they ensure their favourable effect on the surrounding parts of the landscape, which have been transformed or otherwise affected by people (especially arable land and intensively used meadows and pastures). They fulfil a lot of ecological functions and complete the local ecological network. They consist predominantly of Scots pine (Pinus sylvestris), sessile oak (Quercus petrea) and European hornbeam (Carpinus betulus), and in the undergrowth, there are common privet (Ligustrum vulgare), dog rose (Rosa canina), Rubus (Rubus sp.), common dogwood (Swida sanquinea), field maple (Acer campestre), wild service tree (Sorbus torminalis), hawthorn (Crataegus monogyna), common hazel (Corylus avellana), blackthorn (Prunus spinosa), common spindle (Eonymus europaeus) and others.

Most ecological measures of the selected biocorridors and biocentres dealt with the conservation of the current state and eliminating human interferences. Size parameters were suitable in the majority of the elements. Only for the element LBc5 Jeleškový potok stream, it was proposed to broaden the bank covers on both banks of the stream to the minimal length 
of $5 \mathrm{~m}$ by means of leaving natural succession and reduction of interferences into bank covers when working (mowing) the surrounding land parcels. Species composition of all the elements was suitable too, and all the localities represented natural communities. The majority of proposals of management measures of interacting elements were focused on keeping size parameters and conservation of ecotone communities on the borders of forest covers. It was necessary to broaden some of them by directly planting of suitable woody plants (Quercus

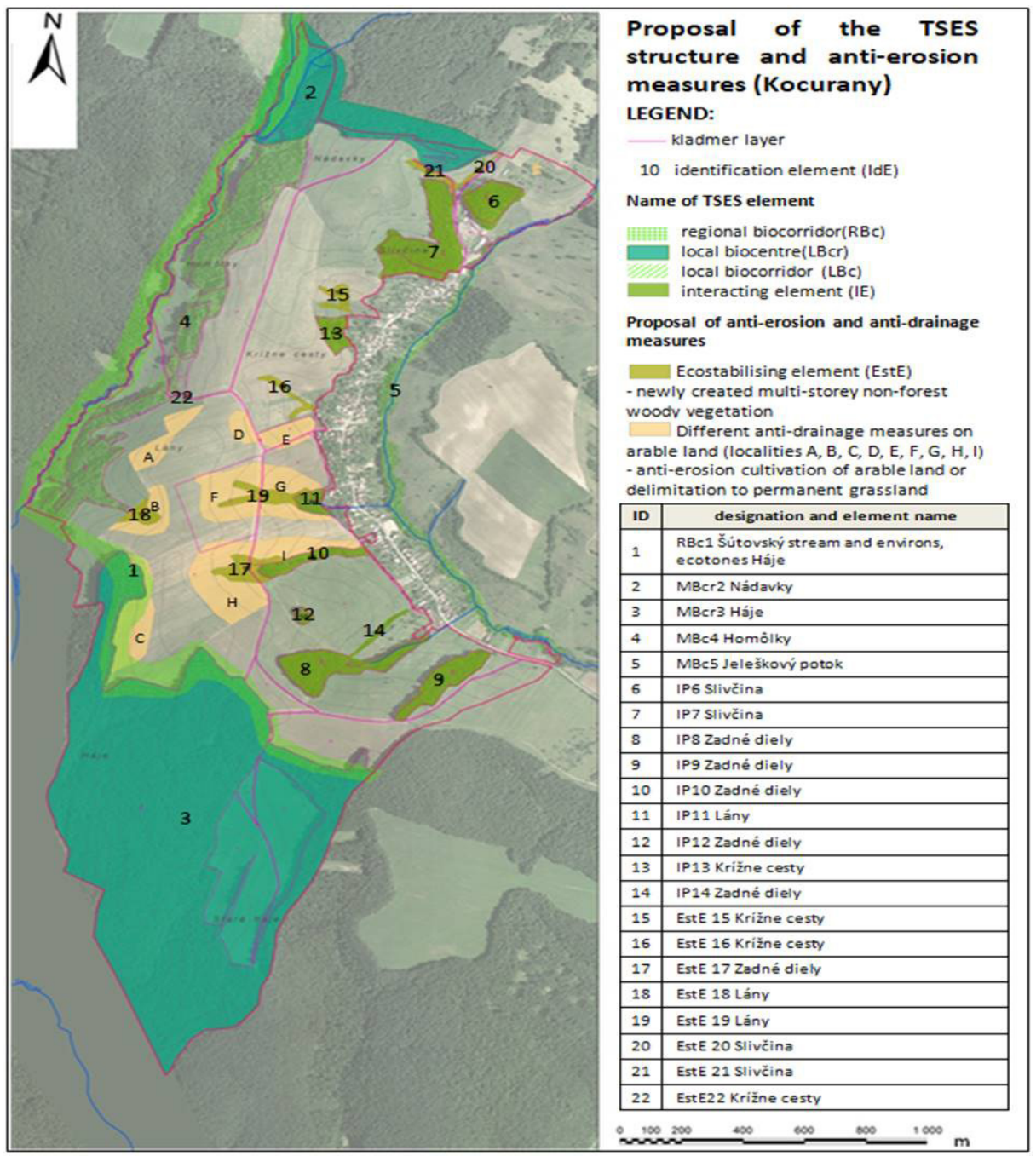

Fig. 2. Proposal of the TSES structure and anti-erosion measures worked out within the project of the Local Territorial System of Ecological Stability for the land consolidation project of the cadastral unit Kocurany (Diviaková et al., 2013). 
robur, Acer campestre) or with the support of succession. It was necessary to remove illegal landfills in some interacting elements.

In the district of the LC project Kocurany, locations were proposed for 8 new ecostabilising anti-erosion elements (EstE15, EstE16, EstE22 - Krížne cesty, EstE17 Zadné diely, EstE18, EstE19 - Lány, EstE20 and EstE21 - Slivčina). These were mainly locations of groups and belts of non-forest woody vegetation, which were multi-layered, created by various species of natural woody plants (Carpinus betulus, Quercus petraea, Acer campestre, Tilia cordata and others), with the formation of noticeable ecotone communities on the borders of proposed elements. The aim of this group of proposals was to improve the overall ecological spatial stability. It was important to propose ecostabilising elements that would improve the retention ability of the landscape: deceleration of water runoff from the landscape, increase of self-cleaning ability of the landscape, ensuring anti-erosion protection of the landscape and so on.

In the localities of arable land with a high threat of water erosion, or at a risk of flooding (near the village area), anti-erosion and drainage measures were proposed. 9 localities were specified (A, B, C, D, E, F, G, H and I) with a need for anti-erosion cultivation (arable land with multi-year fodder plants), or delimitations to permanent grasslands.

6 sites (A, B, D, E, F, G) were to the west of the central part of the intravilan in the local part of the Lány and the remaining $3(\mathrm{C}, \mathrm{H}, \mathrm{I})$ were defined southwards in the neighbouring local part of the Zadné diely.

You can see the proposal of ecological measures of the LTSES project for Kocurany village in Fig. 2.

Currently, there is only intensive agricultural production in some parts of the discussed area. The majority of the permanent grassland is used extensively; it is being overgrown with self-seeding of woody plants (oak, beech, juniper) and with the extension of succession covers (blackthorns, hawthorn, briars, blackberries, etc.).

Due to the change of traditional territory administration, the disappearance of important landscape structures is becoming a serious environmental problem, as well as threatening spatial stability and biodiversity. Species reliant on open areas are especially concerned, because this space is kept as agricultural landscape (by mowing and grazing). Incorrect management or the end of farming lead to overgrowth by succession self-seeding, changing species composition and leading to a decline of sensitive and protected species.

It is, therefore, necessary to implement the following management measures in order to optimally use agricultural land parcels:

- conservation of remaining natural mowing submontane meadows (in the locality of Nádavky),

- conservation of ecotone communities on the border of forest covers,

- conservation of grass and herbaceous communities with the presence of non-forest woody vegetation,

- creation of new ecostabilising elements on agricultural soil with varied species of multilayered non-forest woody vegetation,

- anti-erosion soil cultivation and planting only perennial fodder plants on arable land,

- ensuring protection of bank covers, 
- creation of a protective belt of soil along water streams as a form of delimitation of adjacent land parcels, these belts being registered as having a different functional use to the adjacent land parcels, thereby preventing cultivation up to the edges of water surfaces,

- conservation of the current state with the prevention of modification to bank covers and limitation of crossing Š́tovský streambed by vehicles.

On the land parcels that are used for other non-agricultural purposes, it will be necessary to provide the following management measures:

- conservation of natural forest covers of natural woody plants composition,

- conservation of old cemetery with no interventions to vegetation,

- determination of individual projection units next to the urban land and their consequent transfer to the ownership of the village, so they will correspond with the zones designated for residential construction based on the conclusions from the updated local plan of the village.

\section{Analysis of the proposal of general principles of functional organisation of the territory}

In the district of the LC project Kocurany, several types of land parcels underwent the process of delimitation, that is, integration into a new category of functional use. Their total area ( $82.16 \mathrm{ha}$ ) represented nearly $25 \%$ of the total area of the LC project. The largest area for delimitation (41.18 ha) consisted of arable land, located in the local areas of Lány and Zadné diely, which was transferred to the category of permanent grasslands. Some of the land parcels, registered as other surfaces (2.33 ha) or forest land (2.01 ha), were also transferred into the category of permanent grassland. Certain land parcels, which had been registered as permanent grasslands (9.55 ha) and other surfaces (1.41 ha), underwent the process of delimitation and were transferred for use as arable land. Furthermore, over a considerable area, the process of delimitation was undergone on land parcels, which has previously been categorised as other surfaces around the Jeleškovský potok, (19.09 ha) and permanent grasslands (0.32 ha), but actually consisted of the forest covers, as well as some parcels of arable land ( $0.01 \mathrm{ha})$ over which the forest had spread to such an extent that it was not possible to characterise it as self-seeding woody plants. All these land parcels were re-categorised as forest land parcels. Existing areas of non-forest woody vegetation are still registered as other surfaces. These included covers on the slopes beyond the urban area, which do not have forest characteristics, and also bank covers beside streams. Newly proposed areas for non-forest woody vegetation with ecostabilising function on permanent grasslands $(0.1 \mathrm{ha})$, on forest land parcels ( $0.05 \mathrm{ha})$ and on arable land ( $0.001 \mathrm{ha})$ were, from the point of view of land recording, transferred into the category of other surfaces. Due to its position, the village did not have any areas of development or zones determined for residential construction. Therefore, the demand for the development of residential construction was included in the proposal of GPFOT in compliance with the land plan of the village (Szalay et al., 2013). Land parcels registered as permanent grasslands (3.51 ha), arable lands (2.43 ha), other surfaces $(0.11 \mathrm{ha})$ and forest land parcels $(0.06 \mathrm{ha})$ in areas above the urban area of the village were delimited into the category of built-up area. Consequently, it was necessary 
to ensure the transfer of these projection units into the ownership of the village during the implementation of the LC project.

In the process of the GPFOT proposal creation, the requirements of the Land and Forest Department of the Prievidza District Office were accepted. The proposals of the association of participants of the LC were taken into consideration, and those of people farming on land parcels within the LC project (Agricultural cooperative of shareholders in Koš and the Kocurany Forest and Land Association). Regarding the new proposal, the majority of the landholders agreed that their new land parcels will be rented to the Agricultural cooperative of shareholders in Koš or to another user that has not been established yet. On 21 March 2012, the contract on the establishment of the Kocurany Forest and Land Association was concluded at the general assembly. In compliance with the Forest Management Programme and under the supervision of a professional forest manager, the association wanted to achieve rational management of common land. Based on this, large projection areas of forest land parcels were selected in the GPFOT proposal so that blocks in co-ownership could be projected. At the same time, the closest areas of adjoining cadastral units were taken into consideration. Thus, it will be possible to continue these proposals when projecting the LC of surrounding villages in the future.

In order to prevent or protect against water erosion, three groups of proposals of anti-erosional soil protection were created (anti-erosional organisation of the territory, anti-erosional protection using ecostabilising elements, anti-erosional soil cultivation). Anti-erosional organisation of the territory consisted of the proposal of optimal shape, volume and positional distribution of agricultural land parcels in the landscape. Anti-erosional arable land cultivation in the form of planting perennial fodder plants only was proposed in 5 localities (E, F, G, $\mathrm{H}, \mathrm{I})$. There were locations of arable land at A high risk of erosion located in the local parts of Lány (E, F, G) and Zadné diely (H, I) with the total area of land parcels of 9.61 ha. Anti-erosional protection by ecostabilising elements (EstE15, EstE16, EstE22, EstE23 - Krížne cesty, EstE20, EstE21 - Slivčina) was proposed in 6 localities. It was a proposal of new or extension of existing elements of non-forest woody vegetation on the land parcels with a total area of 2.14 ha. The role of ecostabilising elements is to provide a barrier to water erosion and, during periods of torrential rain, to ensure flood protection of the village urban area.

In order to increase ecological stability and biodiversity, the network of 6 existing TSES elements was established over an area of 99.97 ha (RBc1, LBcr3, LBc4, IE10, IE11, IE13). It was a proposal from a group of measures for the protection of the environment, the aim of which was to ensure connectivity of biotic elements at the local level: hydric and terestric regional biocorridor, local biocentre (forest cover), terestric local biocorridor and the interaction of these 3 elements. From water management measures, the management of hydric and terestric regional biocorridor Śútovský potok and its environs, ecotones Háje (RBc1) was proposed. It was a proposal of maintaining the current state and elimination of interventions to bank covers, as well as a restriction to the crossing Śútovský stream by vehicles.

Land parcels for public facilities were proposed, having a total area of 0.49 ha on two localities (an old cemetery in the southern part of the discussed area and a garden next to a kindergarten). It was necessary to convert the ownership of these parcels so that they became the property of the village. 
Assessment of the rate of integration of ecological measures from the Local Territorial System of Ecological Stability into the general principles of functional organisation within land consolidations

Only 20 localities (total area $119.37 \mathrm{ha}$ ) were reflected in the GPFOT proposal compared to 31 localities (total area $154.34 \mathrm{ha}$ ) in the TSES structure and anti-erosion measures proposal. Due to the specific requirements of the village, a new ecostabilising element with an antierosional function was created in GPFOT (EstE23 element). It was an ecological measure created with an area of 0.22 ha, which was situated on permanent grasslands with the local name Krížne cesty (between the elements IE13 and EstE16).

The following ecological measures were incorporated into GPFOT from the LTSES:

- 6 TSES elements (elements RBc1 Šútovský potok, LBcr3 Háje, LBc4 Homôlky, IE10 Zadné diely, IE11 Lány, IE13 Krížne cesty),

- 5 ecostabilising elements (elements EstE15, EstE16, EstE22 - Krížne cesty, EstE20, EstE21 - Slivčina),

- 5 localities of arable land with the need of anti-erosional soil cultivation (localities E, F, G - Lány and H, I - Zadné diely),

- 4 localities of arable land with the need of delimitation to permanent grasslands (localities A, B, D - Lány and C - Zadné diely).

Of those ecological measures, the following were incorporated into GPFOT but with an adjustment to their areal extent:

- 4 ecological measures (IE10 Zadné diely, IE11 Lány, EstE20 Slivčina, EstE22 Krížne cesty) were incorporated with a 1.47 ha larger areal extent than determined in the LTSES, having a total area of 4.01 ha,

- 7 ecological measures (IE13, EstE15, EstE16 - Krížne cesty, EstE21 Slivčina, locality G - Lány, localities H, I - Zadné diely) were incorporated with 7.57 ha lesser areal extent than determined in the LTSES, having a total area of 6.77 ha.

The absence of 11 other localities can be considered as the biggest deficiency of the GPFOT. These localities were proposed in the LTSES for the implementation of ecological measures (total area 29.09 ha), but were not incorporated from the LTSES into GPFOT:

- 8 TSES elements (elements LBcr2 Nádavky, LBc5 Jeleškový potok, IE6, IE7, IE8, IE9, IE12, IE14 - Zadné diely),

- 3 ecostabilising elements (elements EstE17 Zadné diely, EstE18, EstE19 - Lány).

An overview of the ecological measures, specified in the LTSES and consequently incorporated or not into GPFOT, is shown in Table 1 and Table 2.

\section{Discussion}

In the LC project in the village of Kocurany, the process of creation of LC project documents was, to a large extent, influenced by specific social demands. They were discussed during the whole process of the LC. The proposals were considered and reviewed with the concerned parties. In the process of determining the rate of acceptance of ecological measures, it was found that only 6 elements (out of 14) of the LTSES structure were incorporated into the 
$\mathrm{T}$ a b l e 1. Localities of ecological measures incorporated from the LTSES to GPFOT.

\begin{tabular}{|c|c|c|c|c|c|c|}
\hline \multirow[b]{3}{*}{$\begin{array}{l}\text { Ecological } \\
\text { measures }\end{array}$} & \multirow[b]{3}{*}{ Abbreviation } & \multicolumn{2}{|l|}{ LTSES for LC purposes } & \multicolumn{2}{|l|}{ GPFOT } & \multirow{3}{*}{$\begin{array}{c}\text { Changes in area } \\
\text { from LTSES to } \\
\text { GPFOT }\end{array}$} \\
\hline & & \multicolumn{2}{|c|}{$\begin{array}{l}\text { Proposal of the TSES structure and anti- } \\
\text { erosion measures }\end{array}$} & \multicolumn{2}{|l|}{ Proposal of GPFOT } & \\
\hline & & Name & $\begin{array}{c}\text { Area } \\
\text { [ha] }\end{array}$ & Name & $\begin{array}{l}\text { Area } \\
\text { [ha] }\end{array}$ & \\
\hline \multirow{6}{*}{$\begin{array}{l}\text { Measures for } \\
\text { environmental } \\
\text { protection }\end{array}$} & $\mathrm{Bcr}$ & LBcr3 Háje & 49.54 & LBcr3 Háje & 49.54 & 0.00 \\
\hline & \multirow[t]{2}{*}{$\mathrm{Bc}$} & $\begin{array}{l}\text { RBcl Sútovský stream and } \\
\text { environs, ecotones Háje }\end{array}$ & 25.81 & $\begin{array}{l}\text { RBcl Š́tovský potok and environs, } \\
\text { ecotones Háje }\end{array}$ & 25.81 & 0.00 \\
\hline & & LBc4 Homôlky & 19.30 & LBc4 Homôlky & 19.30 & 0.00 \\
\hline & \multirow[b]{3}{*}{ IE } & IE10 Zadné diely & 1.54 & IE10 Zadné diely & 1.77 & +0.23 \\
\hline & & IE11 Lány & 0.73 & IE11 Lány & 1.37 & +0.64 \\
\hline & & IE13 Krížne cesty & 1.09 & IE13 Krížne cesty & 1.08 & -0.01 \\
\hline \multirow{14}{*}{$\begin{array}{c}\text { Anti-erosion } \\
\text { measures }\end{array}$} & \multirow{5}{*}{$\begin{array}{l}\text { EstE with } \\
\text { anti-erosion } \\
\text { function }\end{array}$} & EstE15 Krížne cesty & 0.68 & EstE15 Krížne cesty & 0.51 & -0.17 \\
\hline & & EstE16 Krížne cesty & 0.58 & EstE16 Krížne cesty & 0.44 & -0.14 \\
\hline & & EstE20 Slivčina & 0.23 & EstE20 Slivčina & 0.63 & +0.40 \\
\hline & & EstE21 Slivčina & 0.57 & EstE21 Slivčina & 0.10 & -0.47 \\
\hline & & EstE22 Krížne cesty & 0.04 & EstE22 Krížne cesty & 0.24 & +0.20 \\
\hline & \multirow{9}{*}{$\begin{array}{l}\text { Anti-erosion } \\
\text { and } \\
\text { anti-drainage } \\
\text { measures on } \\
\text { arable land }\end{array}$} & $\begin{array}{l}\text { Locality A: anti-erosion arable } \\
\text { land cultivation or delimitation to } \\
\text { permanent grasslands }\end{array}$ & 1.90 & $\begin{array}{l}\text { Locality A: arable land delimited to } \\
\text { permanent grasslands }\end{array}$ & 1.90 & 0.00 \\
\hline & & $\begin{array}{l}\text { Locality B: anti-erosion arable } \\
\text { land cultivation or delimitation to } \\
\text { permanent grasslands }\end{array}$ & 2.27 & $\begin{array}{l}\text { Locality B: arable land delimited to } \\
\text { permanent grasslands }\end{array}$ & 2.27 & 0.00 \\
\hline & & $\begin{array}{l}\text { Locality C: anti-erosion arable } \\
\text { land cultivation or delimitation to } \\
\text { permanent grasslands }\end{array}$ & 3.70 & $\begin{array}{l}\text { Locality C: arable land delimited to } \\
\text { permanent grasslands }\end{array}$ & 3.70 & 0.00 \\
\hline & & $\begin{array}{l}\text { Locality D: anti-erosion arable } \\
\text { land cultivation or delimitation to } \\
\text { permanent grasslands }\end{array}$ & 0.88 & $\begin{array}{l}\text { Locality D: arable land delimited to } \\
\text { permanent grasslands }\end{array}$ & 0.88 & 0.00 \\
\hline & & $\begin{array}{l}\text { Locality E: anti-erosion arable } \\
\text { land cultivation or delimitation to } \\
\text { permanent grasslands }\end{array}$ & 1.27 & $\begin{array}{l}\text { Locality E: arable land with } \\
\text { anti-erosion cultivation }\end{array}$ & 1.27 & 0.00 \\
\hline & & $\begin{array}{l}\text { Locality F: anti-erosion arable } \\
\text { land cultivation or delimitation to } \\
\text { permanent grasslands }\end{array}$ & 3.70 & $\begin{array}{l}\text { Locality F: arable land with } \\
\text { anti-erosion cultivation }\end{array}$ & 3.70 & 0.00 \\
\hline & & $\begin{array}{l}\text { Locality G: anti-erosion arable } \\
\text { land cultivation or delimitation to } \\
\text { permanent grasslands }\end{array}$ & 3.00 & $\begin{array}{l}\text { Locality G: arable land with } \\
\text { anti-erosion cultivation }\end{array}$ & 2.46 & -0.54 \\
\hline & & $\begin{array}{l}\text { Locality H: anti-erosion arable } \\
\text { land cultivation or delimitation to } \\
\text { permanent grasslands }\end{array}$ & 5.96 & $\begin{array}{l}\text { Locality } \mathrm{H} \text { : arable land with } \\
\text { anti-erosion cultivation }\end{array}$ & 0.22 & -5.74 \\
\hline & & $\begin{array}{l}\text { Locality I: anti-erosion arable } \\
\text { land cultivation or delimitation to } \\
\text { permanent grasslands }\end{array}$ & 2.46 & $\begin{array}{l}\text { Locality I: arable land with } \\
\text { anti-erosion cultivation }\end{array}$ & 1.96 & -0.5 \\
\hline
\end{tabular}

Notes: LTSES - Local Territorial System of Ecological Stability; GPFOT - General Principles of Functional Organisation of the Territory; LC - land consolidation; $\mathrm{Bcr}$ - biocentre; $\mathrm{LBcr}$ - local biocentre; $\mathrm{Bc}$ - biocorridor; $\mathrm{RBc}$ - regional biocorridor; LBc - local biocorridor; IE - interacting element; EstE - ecostabilising element.

GPFOT (i.e., 43\% integration rate) and 15 anti-erosion measures out of 17 were incorporated into the GPFOT (i.e. $88 \%$ integration rate). This incomplete projection was most likely the result of the demands of users or landholders of the land parcels concerned. 
T a b l e 2. Localities of ecological measures not incorporated from the LTSES to GPFOT.

\begin{tabular}{|c|c|c|c|c|c|c|}
\hline & & \multicolumn{2}{|c|}{ LTSES for LC purposes } & \multicolumn{2}{|c|}{ GPFOT } & \multirow{2}{*}{$\begin{array}{l}\text { Changes in } \\
\text { area from } \\
\text { LTSES to } \\
\text { GPFOT }\end{array}$} \\
\hline & & \multicolumn{2}{|c|}{$\begin{array}{l}\text { Proposal of the TSES structure } \\
\text { and anti-erosion measures }\end{array}$} & \multicolumn{2}{|c|}{ Proposal of GPFOT } & \\
\hline $\begin{array}{c}\text { Ecological } \\
\text { measures }\end{array}$ & Abbreviation & Name & $\begin{array}{c}\text { Area } \\
{[\text { ha] }}\end{array}$ & Name & $\begin{array}{c}\text { Area } \\
{[\mathrm{ha}]}\end{array}$ & $\begin{array}{c}\text { Area } \\
{[\text { ha] }}\end{array}$ \\
\hline \multirow{12}{*}{$\begin{array}{l}\text { Measures for } \\
\text { environmental } \\
\text { protection }\end{array}$} & $\mathrm{Bcr}$ & LBcr2 Nádavky & 8.80 & - & 0.00 & -8.80 \\
\hline & $\mathrm{Bc}$ & LBc5 Jeleškový stream & 1.10 & - & 0.00 & -1.10 \\
\hline & \multirow{6}{*}{ IE } & IE6 Slivčina & 2.37 & - & 0.00 & -2.37 \\
\hline & & IE7 Slivčina & 5.83 & - & 0.00 & -5.83 \\
\hline & & IE8 Zadné diely & 4.06 & - & 0.00 & -4.06 \\
\hline & & IE9 Zadné diely & 2.80 & - & 0.00 & -2.80 \\
\hline & & IE12 Zadné diely & 0.27 & - & 0.00 & -0.27 \\
\hline & & IE14 Zadné diely & 0.44 & - & 0.00 & -0.44 \\
\hline & \multirow{4}{*}{ EstE } & EstE17 Zadné diely & 1.41 & - & 0.00 & -1.41 \\
\hline & & EstE18 Lány & 0.72 & - & 0.00 & -0.72 \\
\hline & & EstE19 Lány & 1.29 & - & 0.00 & -1.29 \\
\hline & & - & - & EstE23 & 0.22 & +0.22 \\
\hline
\end{tabular}

Notes: LTSES - the Local Territorial System of Ecological Stability; GPFOT- General Principles of Functional Organisation of the Territory; LC - land consolidation; $\mathrm{Bcr}$ - biocentre; $\mathrm{LBcr}$ - local biocentre; $\mathrm{Bc}$ - biocorridor; $\mathrm{LBc}$ - local biocorridor; IE - interacting element; EstE - ecostabilising element.

T a b l e 3. Rate of integration of ecological measures from the LTSES into GPFOT in selected municipalities of the region of Prievidza.

\begin{tabular}{|c|c|c|c|c|c|c|c|}
\hline \multirow{2}{*}{\multicolumn{2}{|c|}{$\begin{array}{c}\text { District of the LC project } \\
\text { of a municipality }\end{array}$}} & \multicolumn{2}{|c|}{ Nováky } & \multicolumn{2}{|c|}{ Pravenec } & \multicolumn{2}{|c|}{ Horná Ves } \\
\hline & & \multirow{2}{*}{$\begin{array}{c}\text { LTSES } \\
0 \\
\end{array}$} & \multirow{2}{*}{$\begin{array}{c}\text { GPFOT } \\
0\end{array}$} & \multirow{2}{*}{$\begin{array}{c}\text { LTSES } \\
0 \\
\end{array}$} & \multirow{2}{*}{$\begin{array}{c}\text { GPFOT } \\
0\end{array}$} & \multirow{2}{*}{$\begin{array}{c}\text { LTSES } \\
0 \\
\end{array}$} & \multirow{2}{*}{$\begin{array}{c}\text { GPFOT } \\
0 \\
\end{array}$} \\
\hline ARTSES & $\mathrm{Bcr}$ & & & & & & \\
\hline & $\mathrm{Bc}$ & 0 & 0 & 0 & 0 & 1 & 1 \\
\hline \multirow{2}{*}{ RTSES } & $\mathrm{Bcr}$ & 2 & 2 & 1 & 0 & 3 & 3 \\
\hline & $\mathrm{Bc}$ & 3 & 3 & 2 & 1 & 4 & 4 \\
\hline \multirow[t]{3}{*}{ LTSES } & $\mathrm{Bcr}$ & 17 & 17 & 3 & 3 & 11 & 11 \\
\hline & $\mathrm{Bc}$ & 10 & 8 & 4 & 4 & 11 & 11 \\
\hline & IE & 15 & 12 & 25 & 10 & 65 & 65 \\
\hline \multicolumn{2}{|c|}{ Ecological measures - total } & 47 & 42 & 35 & 18 & 95 & 95 \\
\hline \multicolumn{2}{|c|}{ Integration [\%] } & - & 89 & - & 51 & - & 100 \\
\hline
\end{tabular}

Notes: ARTSES - Above-Regional Territorial System of Ecological Stability; RTSES - Regional Territorial System of Ecological Stability; LTSES - Local Territorial System of Ecological Stability; GPFOT- General Principles of Functional Organisation of the Territory; LC - land consolidations; Bcr - biocentre; Bc - biocorridor; IE - interacting element. 
Similar issues of the implementation of ecological measures in the LC projecting were also encountered in other cadastral units of the region of Prievidza (Belaňová, 2014). 3 cadastral territories were compared and in 2 of them, an incomplete rate of integration was identified (Table 3). With the focus on the creation of the TSES structure, several imperfections of spatial and planning practice were identified in the practical verification and application of the LTSES in LC planning in model territories. Project architects of land consolidations had quality materials from the processed project documentations of the LTSES for the LC purposes, which were integrated to different extent into each LC project.

More positive conclusions were drawn from a study of the rate of ecological measure integration into the LC in selected municipalities within the regions of Žilina and Zlaté Moravce, in the northern and south-western parts of the Slovak Republic (Belaňová, Diviaková, 2015). From the 8 municipalities compared, an incomplete rate of integration of ecological measures was identified in only 2 of them. In one municipality, even more localities were selected for the implementation of ecological measures than were proposed in the LTSES.

Currently, the LC plans have been completed for only 421 cadastral units out of 3538 cadastral units in Slovakia, that is, only 12\% (http://www.kpu.sk/komplexne-pu/prehladna-mapa-pozemkovych-uprav-v-sr). The existing pace of the LC implementation does not provide even a theoretical possibility of a complete organisation of landholding in Slovakia within two or three decades.

This 'complex' LC has been financed by the Rural Development Programme, which represents the assistance from EU funds and aims to solve many of the problems concerning the countryside in a single project. This complexity leads to time and financial difficulties with these local projects. Another reason for the small number of the completed LC projects in Slovakia is that the current situation is convenient for landholders, who buy these land parcels cheaply or rent them using teams of lawyers and dealers (https://miroslavziak1.blog.sme. sk/c/465635/pozemkove-upravy-vlastnikom-pody-pomozu-ale.html). The solution may be to better define the time and financial schedule of the LC, with reasonably set technical parameters, as well as ensuring LC financing from several sources. This is considered as a key step necessary for the larger implementation of the LC into practice (http://www.kpu.sk/ aktuality/komplexne-komasacne-jednoduche-pozemkove-upravy).

These solutions would also result in a more reliable rate of integration of quality proposals of ecological measures into the LC projects. It can then be stated that TSES projects (a base of ecological measures), as a compulsory material for the LC, are very reliable documents for the implementation of ecological measures into the landscape. This is proved by several practical outputs of the LTSES projects for the LC, which have been published from different points of view. Ružičková et al. (2010) dealt with the problem of fragmentation of natural biotopes and the importance of renewal of ecological networks, especially via the local TSES proposed in the LC. They compared two distant municipalities (Tuchyňa - western Slovakia, Štôla - eastern Slovakia).

In the 3 villages of western Slovakia (Hájské, Vel'ké Vozokany, Kanianka), which were of different geomorphological types of relief, the development of landscape structure was studied chronologically. In the latter of the three studied time periods, they observed positive changes in the landscape due to the implementation of the TSES proposals into the LC 
projects. New landscape elements were created using the LC and it lead to a diversity increase within landscape, which positively affected the ecological stability of the landscape and ensured prevention of destructive processes in the landscape (Muchová, Petrovič, 2010).

Within the intensively used landscape in the cadastral unit of Klasov, Moyzeová and Kenderessy (2015) focused on the creation of an ecological network through revitalisation of existing fragments of natural biotopes and creation of new ones, as well as system of ecostabilising measures and their management. They presented a functional framework of the TSES in the territory, whose implementation through the LC will contribute to an increase of territorial diversity and improvement of spatial ecological stability. The TSES project for the purposed LC is presented as a tool, which contributes to adaptation to climate changes, to support economic, territorial and social cohesion and to strengthen protection of natural and cultural heritage.

Muchová et al. (2016) pointed to problems within the Žitava river basin, which restrict rural development (low ecological stability of landscape, frequent flooding, increase of soil erosion, etc.). They highlighted the main problems of water resource management and environmental protection. They graphically presented basic topics that are important for the assessment and proposal of ecostabilising measures, which could protect the area from natural disasters.

\section{Conclusion}

There is a constant development in the landscape, which is more and more influenced by human activity. Landscape components are mutually affected and it continuously gains new structure and properties. Efforts to improve structure, as well as use of agricultural land parcels are very urgent in many cases. A decrease was observed in the ecological stability of the landscape, an increase of water and wind erosion and degradation of soil cover, due to the use of excessive amount of chemicals. The increase of concentration of production leads to other harmful impacts on the environment, for example, eutrophication of water courses, increase of nitrates in underground water and so on. It is obvious in these cases that from the point of view of infrastructure, the territory is not economically organised and used, or it is necessary to implement anti-erosion or other ecological measures within it, which require interventions to the landscape and change of proprietary rights and relations of use. It is not possible to successfully apply proposals and measures following from planning processes without the arrangement of ownership and implementation of several acts at the level of land registry. For the realisation of individual proposals and measures in specific areas, the land parcels must have owners. The most suitable method is to have a new organisation of land parcels and ensure that there are no problem accessing them. The solution to these problems is land consolidation, which - in compliance with the law on LC - enables the rational spatial organisation of the land parcels via the LC project. The LC project is implemented in accordance with the requirements and conditions of environmental protection, sustainable development principles and creation of the TSES structure.

The TSES concept in Slovakia can be considered as the most important intersection of landscape and ecological principles into real ecological policy and into spatial and planning 
practice. The main contribution of the TSES for the LC project is its implementation stage when the TSES at the local level becomes a real tool for protection and design of the landscape, or revitalisation and ecologisation of agricultural landscape. Based on this, the TSES implementation has multifunctional and society-wide importance.

\section{Acknowledgements}

This paper was supported by the VEGA scientific grant agency, project No. 1/0096/16.

\section{References}

Bani, L., Baietto, M., Bottoni, L. \& Massa R. (2002). The use of focal species in designing a habitat network for a lowland area of Lombardy, Italy. Conserv. Biol., 16, 826-831. DOI: 10.1046/j.1523-1739.2002.01082.x.

Bastian, O. \& Schreiber K.F. (Eds.) (1994). Analyse und ökologische bewertung der landschaft. Stuttgart: Fischer Verlag Jena.

Baudry, J., Bunce, R.G.H. \& Burel F. (2000). Hedgerows: An international perspective on their origin, function and management. J. Environ. Manag., 60, 7-22. DOI: 10.1006/jema.2000.0358.

Belaňová, E. (2014). Krajinno-ekologické aspekty integrovaného manažmentu krajiny v územnom pláne a v projekte pozemkových úprav. Dizertačná práca, Zvolen.

Belaňová, E. \& Diviaková A. (2015). Porovnanie uplatnenia návrhov na tvorbu kostry MÚSES v projektovaní pozemkových úprav. Ekologické Štúdie, 6(1), 69-80.

Bennett, A.F. (1999). Linkages in the landscape: The role of corridors and connectivity in wildlife conservation. Gland, Cambridge: IUCN.

Bonfanti, P., Fregonese, A. \& Sigura M. (1997). Landscape analysis in areas affected by land consolidation. Landsc. Urban Plann., 37(1-2), 91-98. DOI: 10.1016/S0169-2046(96)00373-8.

Borec, A. (2000). The significance of land consolidation for the development of farmland in Slovenia then and now. Ber. Landwirtsch., 78, 320-334.

Brandt, J. (1995). Ecological networks in Danish planning. Landschap, 12 (3), 63-76.

Buček, A. \& Lacina J. (1979). Biogeografická diferenciace krajiny jako jeden z ekologických podkladů pro územní plánování. Územní Plánování a Urbanismus, 6, 382-387.

Buček, A., Lacina, J. \& Löw J. (1986). Územní systémy ekologické stability krajiny. Životné Prostredie, 20(2), 82-86.

Buček, A. \& Lacina J. (1993). Územní systémy ekologické stability. Veronica, 8(1), 48.

Cook, E.A. \& van Lier H.N. (Eds.) (1994). Landscape planning and ecological networks. Lausanne, New York, Oxford, Shannon, Tokyo: Elsevier.

Crecente, R., Alvarez, C. \& Frau U. (2002). Economic, social and environmental impact of land consolidation in Galicia. Land Use Policy, 19, 135-147. DOI: 10.1016/S0264-8377(02)00006-6.

Diviaková, A., Kočický, D., Novikmec, M. \& Svitok M. (2013). Miestny územný systém ekologickej stability pre projekt pozemkových úprav k.ú. Kocurany (okres Prievidza). Zvolen: TU.

Doubrava, D. \& Martének J. (2015). Vymezení ÚSES v návrzích komplexních pozemkových úprav, co konktétně to znamená? Sborník ze semináre ÚSES - zelená páter krajiny a Ekologické síte v krajine (pp. 12-17). Brno: AOPaK ČR.

Dumbrovský, M. \& Kolářová D. (1995). Zásady navrhování územních systémů ekologické stability v rámci procesu komplexních pozemkových úprav. Praha-Zbraslav: VÚMaOP.

Eichenauer, M. \& Joeris D. (1994). The historical relationship between land consolidation and nature conservation. Ber. Landwirtsch., 72, 329-450.

Fabos, J.Gy. (2005). Introduction and overview: the greenway movement, uses and potentials of greenways. Landsc. Urban Plann., 33, 1-13. DOI: 10.1016/0169-2046(95)02035-R.

Forman, R.T.T. \& Baudry J. (1984). Hedgerows and hedgerow networks in landscape ecology. Environ. Manag., 8, 495-510. DOI: 10.1007/BF01871575.

Forman, T.T.F. \& Godron M. (1993). Landscape ecology (in Czech). Praha: Academia.

Gorton, M. \& White J. (2003). The politics of agrarian collapse: Decollectivisation in Moldova. East European Politics and Societies, 17(2), 305-331. DOI: 10.1177/0888325403017002006. 
Hootsmans, M. \& Kampf H. (2004). Ecological networks: Experiences in Netherlands. The Netherlands: Ministry of Agriculture, Nature and Food Quality.

Izakovičová, Z., Štefunková, D. \& Ružička M. (2000). The model of formation of the territorial sytem of ecological stability on the local level for land adjustment. Ekológia (Bratislava), 19, 268-275.

Izakovičová, Z. \& Swiader M. (2017). Budovanie ekologických sietí na Slovensku a v Pol’sku. Ekológia (Bratislava), 36(4), 303-322. DOI: 10.1515/eko-2017-0025.

Jedicke, E. (1994). Biotopverbund-Grundlagen und Maßnahmen einer neuen Naturschutz strategie. Stuttgart:Verlag Eugen Ulmer.

Jongman, R.H.G. (1995). Nature conservation planning in Europe: developing ecological networks. Landsc. Urban Plann., 32, 169-183. DOI: 10.1016/0169-2046(95)00197-O.

Jongman, R.H.G., Külvik, M. \& Kristiansen I. (2004). European ecological networks and greenways. Landsc. Urban Plann., 68, 305-319. DOI: 10.1016/S0169-2046(03)00163-4.

Jongman, R.H.G. (2008). Ecological networks, from concept to implementation. In S.K. Hong, N. Nakagoshi, B. Fu \& Y. Morimoto (Eds.), Landscape ecological applications in man-influenced areas (pp. 57-69). Netherlands: Springer. DOI: $10.1007 / 1-4020-5488-2$.

Julény, A., Julény, A. \& Muchová Z. (2017). Efektívne nástroje obnovy vidieckej krajiny. In L. Miklós \& A. Diviaková (Eds.). Ciele trvalo udržatelného rozvoja: méta integrovaného manažmentu životného prostredia (pp. 95-104). Zborník pôvodných vedeckých prác. Zvolen.

Kaulich, K. (2012). Komplexní pozemkové úpravy jako nástroj k vytváření ÚSES. Ochrana Př́rody, 6, 28-31.

Kocián, J. (2013). Rešení ÚSES v pozemkové úprave - formalita nebo zásadní záležitost. Sborník ze semináre ÚSES - zelená páter krajiny a Ekologické síte v krajine (pp. 70-74). Brno.

Komora pozemkových úprav: <http://www.kpu.sk/aktuality/komplexne-komasacne-jednoduche-pozemkove-upravy>. Accessed 16 May 2018.

Komora pozemkových úprav: <http://www.kpu.sk/komplexne-pu/prehladna-mapa-pozemkovych-uprav-v-sr>. Accessed 16 May 2018.

Krchňavá, M. et al. (2013). Projekt pozemkových úprav v k.ú. Kocurany, úvodné podklady - Všeobecné zásady funkčného usporiadania územia. Technická správa. Žilina: Geodézia.

Lammers, G.W. \& Zadelhoff F.J. (1996). The Dutch national ecological network. In P. Nowicki, G. Bennett, D. Middleton, S. Rientjes \& R. Wolters (Eds.), Perspectives on ecological network (pp. 101-113). ECNC Publications Series on Man Nature, Vol. 1. Tilburg: European Centre for Nature Conservation.

Löw, J. et al. (1988). Návod na navrhování územních systémů ekologické stability krajiny. Podniková metodika. Praha: Agroprojekt Brno.

Mann, Ch.C. \& Plummer M.L. (1995). Are wildlife corridors the right path? Science, 270, 1428-1430. DOI: 10.1126/ science.270.5241.1428.

Michalko, J., Berta, J. \& Magic D. (1986). Geobotanická mapa ČSSR. Slovenská republika. Bratislava: Veda, vydavatel'stvo SAV.

Miklós, L. \& Hrnčiarová T. (Eds.) (2002). Atlas krajiny Slovenskej republiky. Bratislava: MŽP, Banská Bystrica: SAŽP.

Miklós, L., Diviaková, A. \& Izakovičová Z. (2011). Ekologické siete a územné systémy ekologickej stability. Zvolen: TU.

Míchal, I. et al. (1991). Územní zabezpečování ekologické stability: teorie a praxe. Praha: MŽP ČR.

Míchal, I. (1992). Ekologická stabilita. Brno: Veronica.

MP SR (2004). Pozemkové úpravy. Metodický návod. Všeobecná čast'. Konanie o začatí pozemkových úprav a príprava realizácie spoločných zariadenía opatrení, aktualizovaná verzia. Bratislava: MP SR.

Moyzeová, M. \& Kenderessy P. (2015). Territorial systems of ecological stability in land consolidation projects (example of proposal for the LSES of Klasov Village, Slovac Republic), Ekológia (Bratislava), 34(4), 356-370. DOI: 10.1515/eko-2015-0032.

Muchová, Z., Vanek, J., Halaj, P., Hrnčiarová, T., Konc, L., Raškovič, V., Stred’anská, A., Šimonides, I. \& Vašek A. (2009). Metodické štandardy projektovania pozemkových úprav. Nitra: SPU.

Muchová, Z. \& Petrovič F. (2010). Changes in the landscape due to land consolidations. Ekológia (Bratislava), 29, 140-157. DOI: 10.4149/ekol_2010_02_140.

Muchová, Z., Hrnčiarová, T. \& Petrovič F. (2013). Miestny územný systém ekologickej stability na účely pozemkových úprav. Nitra: SPU.

Muchová, Z., Leitmanová, M. \& Petrovič F. (2016). Possibilities of optimal land use as a consequence of lessons learned from land consolidation projects (Slovakia). Ecological Engineering, 90, 294-306. DOI: 10.1016/j.ecoleng.2016.01.018. 
Muchová, Z., Konc, L. \& Petrovič F. (2018). Land plots valuation in land consolidation in slovakia: A need for a new approach. International Journal of Strategic Property Management, 22(5), 372-380. DOI: 10.3846/ ijspm.2018.5221.

Múdry, P., Halamová, Z., Majzlanová, E., Majzlan, O., Nováková, K. \& Šteffek J. (1994). Regionálny územný systém ekologickej stability okresu Prievidza. Banská Štiavnica: Ekotrust.

Naveh, Z. \& Lieberman A.S. (1994). Landscape ecology: theory and application. Springer-Verlag.

Opdam, P., Foppen, R., Reijnen, R. \& Schotman A. (1995). The landscape ecological approach in bird conservation: integrating the metapopulation concept into spatial planning. Ibis, 137, S139-S146. DOI: 10.1111/j.1474919X.1995.tb08434.x.

Rosenberg, D.K., Noon, B.R. \& Meslow E.C. (1997). Biological corridors: form, function and efficacy. BioScience, 47, 677-687. DOI: 10.2307/1313208.

Roy, V. \& Blois S. (2008). Evaluating hedgerow corridors for the conservation of native forest herb diversity. Biol. Conserv., 141, 298-307. DOI: 10.1016/j.biocon.2007.10.003.

Ružičková, H., Halada, L., Jedlička, L. \& Kalivodová E. (Eds.) (1996). Biotopy Slovenska. Príručka k mapovaniu a katalóg biotopov. Bratislava: ÚKE SAV.

Ružičková, J. (2006). ÚSES a projekty pozemkových úprav na Slovensku - Aktuálny stav a metodické aspekty. Sborník ze semináre ÚSES - zelená páter krajiny a Ekologické síte v krajine (pp. 110-117). Brno: AOPaK ČR.

Ružičková, J., Miklošovičová, A. \& Moravčíková Z. (2010). Ecological networks in Slovakia, particularities on the local level in land consolidation projects. Ecology \& Safety, 4(2), 389-417. http://www.science-journals.eu

Sepp, K. \& Kaasik A. (Eds.) (2002). Development of National Ecological Networks in the Baltic countries in the framework of the Pan-European Ecological Network. Warszawa: IUCN.

Sklenička, P. (2002). Temporal changes in the pattern of a Bohemian agricultural landscape during the period 1938 1998. Ekológia (Bratislava), 21, 181-191.

SME Blog: <https://miroslavziak1.blog.sme.sk/c/465635/pozemkove-upravy-vlastnikom-pody-pomozu-ale.html>. Accessed 14 May 2018.

Smith, D. \& Hellmund P.C. (Eds.) (1993). Ecology of Greenways, Design and function of linear conservation areas. Minnesota: University of Minnesota Press.

Szalay, G. et al. (2013). Územný plán (sídelného útvaru) obce Kocurany. Čistopis, zmeny a doplnky č. 1. Prievidza: AGS Ateliér.

Urban, J., Dobrucká, A., Bujnák, J., Vanek, J. \& Vašek A. (2013). Land consolidation tool to resolve the fragmentation of land ownership, land revitalization and rural development (in Slovak). Bratislava: Komora pozemkových úprav SR.

Wrbka, T., Stocker-Kiss, A., Schmitzberger, I. \& Peterseil J. (2005). Network Landscapes of Austria - Identification and Ecological Assessment. In É. Konkoly Gyuró (Ed.), Greenways. Conference Presentations on Ecological Corridors, Green Corridors (pp. 47-62). Sopron.

Zákon č. 330/1991 Zb. o pozemkových úpravách, usporiadaní pozemkového vlastníctva, pozemkových úradoch, pozemkovom fonde a o pozemkových spoločenstvách v znení neskorších predpisov (zákon o PÚ).

Zelinka, L. (2001). Pozemkové úpravy a ich význam pri zaistovaní stability krajiny. In V. Konrád a kol. (Eds.), Súčasný stav a perspektívy ekológie a environmentalistiky: zborník z medzinárodnej vedeckej konferencie pri príležitosti desiateho výročia založenia FEE (pp. 241-244). Zvolen: TU. 